Review

\title{
Project HARP
}

\author{
${ }^{1}$ Relly Victoria Petrescu, ${ }^{2}$ Raffaella Aversa, ${ }^{3}$ Bilal Akash, ${ }^{2}$ Antonio Apicella and \\ ${ }^{1}$ Florian Ion Tiberiu Petrescu \\ ${ }^{1}$ ARoTMM-IFToMM, Bucharest Polytechnic University, Bucharest, (CE), Romania \\ ${ }^{2}$ Advanced Material Lab, Department of Architecture and Industrial Design, \\ Second University of Naples, 81031 Aversa (CE), Italy \\ ${ }^{3}$ Dean of School of Graduate Studies and Research, American University of Ras Al Khaimah, UAE
}

Article history

Received: 21-10-2017

Revised: 27-10-2017

Accepted: 06-11-2017

Corresponding Author: Florian Ion Tiberiu Petrescu ARoTMM-IFToMM, Bucharest Polytechnic University, Bucharest, (CE), Romania E-mail: scipub02@gmail.com
Abstract: The HARP project, abbreviated from the High Altitude Project, was considered a joint project of the United States Department of Defense and Canada's Department of Defense, originally designed to study low-cost re-entry vehicles. Generally, such projects used rocket launchers to launch missiles, costly and often inefficient. The HARP project used a non-rocket space launch method based on a very large weapon capable of sending objects at high altitudes using very high speeds. Beginning in 1961, the HARP project was largely created due to the concerns and insistence of the talented engineer Gerald Bull, a controversial ballistics engineer and he and his project, but ultimately successful, the engineer who led the entire project. Bull developed the high-speed weaponry technique while working on the Ballistic Missile (ABM) and Intercontinental Ballistic Missile (ICBM) research at CARDE in the 1950s, firing high-speed interceptor rocket models, unlike other researchers who proposed to use the construction of higher wind tunnels, which would have been much more expensive. The ABM project eventually ended without providing a working system, but Bull was convinced that the missile systems he developed would have had potential and in this way, he began to look for other ways of using technology. He clearly needed the trust and funding of his project. Funding for this project came from the Defense Production Department in the form of a $\$ 500,000$ grant and a \$ 200,000 loan from the McGill Board of Governors. The United States has been testing new ICBM systems and has requested repeated testing of new reentry vehicles. Bull suggested that the program could be run through its method with much lower spending if the test vehicles would be lifted from a large cannon, unlike the classic rocket method. This would also allow the test program to be very accelerated since repeated pulling was easy to arrange compared to the repeated use of the missiles. The key concept was the use of an oversized gun that throws a sub-dimensional vehicle mounted in a shoe, allowing it to be pulled (thrown, ejected) with a very high acceleration, reaching very high speeds. The entire assembly of the test cannon was embedded in a mixture of sand and epoxy, proving more than capable of withstanding the launching rigors. The project was based on a flight line at Seawell Airport in Barbados at $13.077221^{\circ} \mathrm{N} 59.475641^{\circ} \mathrm{W}$, of which the shells were pulled east to the Atlantic Ocean using a 16 inch (410 $\mathrm{mm}$ ) long, $(20.5 \mathrm{~m})$; the cannula was then expanded (doubled) to the length of $(41 \mathrm{~m})$. In 1966, the third and final 16-inch cannon was installed at a new test site in Yuma, Arizona. On November 18, 1966, the Yuma pistol pulled a $(180 \mathrm{~kg})$ Martlet 2 projectile at a speed of $2100 \mathrm{~m} / \mathrm{s}$, sending it briefly into space and setting an altitude of $180 \mathrm{~km}$ (110 miles).

Keywords: Unmanned, US Army, The HARP Project, High Altitude Project, Very Large Weapon, Sending Objects at High Altitudes, Very High Speeds 


\section{Introduction}

The HARP project, abbreviated from the High Altitude Project, was considered a joint project of the US Department of Defense and Defense, initially designed to study low-cost vehicles. Generally, such projects used rocket launchers to launch missiles, costly and often inefficient. The HARP project used a non-rocket space launching method based on a very large weapon capable of sending objects at high altitudes using very high speeds.

Since 1961, the HARP project has been created largely because of the preoccupations and insistence of talented engineer Gerald Bull, a controversial ballistic engineer and he and his project, but eventually the successful engineer who led the whole project. Bull developed high-speed weapon technology while working on ballistic missiles and intercontinental CARDS (ICBM) in the 1950s, designing high-speed interceptor rocket models, unlike other researchers, the tunnel would have been more expensive. The ABM project eventually ended without providing a working system, but Bull was convinced that the missile systems he developed would have had potential and so he started looking for other ways of using the technology. He clearly needed the trust and funding of his project. Funding for this project came from the Defense Production Department in the form of a $\$ 500,000$ grant and a $\$ 200,000$ loan from Governor McGill Council (HARP Project, Wikipedia), Fig. 1.

The United States is testing new ICBM systems and has called for repeated testing of new reentry vehicles. Bull suggested that the program could be executed by its method, with much lower costs if the test vehicles were lifted from a large cannon, unlike the classic rocket method. This would also allow the test program to be very accelerated, as repeated pulling was easy to arrange compared to a repeated use of missiles. The key concept was the use of an oversized weapon that throws a subdimensional vehicle mounted in a shoe, allowing it to be pulled (thrown, pulled out) with a very high acceleration, reaching very high speeds. The entire test channel assembly was incorporated into a mixture of sand and epoxy, proving more than capable of withstanding the rigidity of the launch.

The project is based on a flight line at Seawell Airport in Barbados at $13.077221^{\circ} \mathrm{N} 59.475641{ }^{\circ} \mathrm{W}$, when the shells were pulled east of the Atlantic using a 16.5 inches $(415 \mathrm{~mm})$ long double $(20.5 \mathrm{~m})(41 \mathrm{~m}) 1$. In 1966, the third and last 16-inch cannon was installed at a new test site in Yuma, Arizona. On November 18, 1966, the Yuma pistol pulled an $84 \mathrm{~kg}$ Marlet 2 projectile at a speed of $2100 \mathrm{~m} / \mathrm{s}$, sending it briefly into space and setting an altitude of $180 \mathrm{~km}$ (110 miles), Fig. 2.

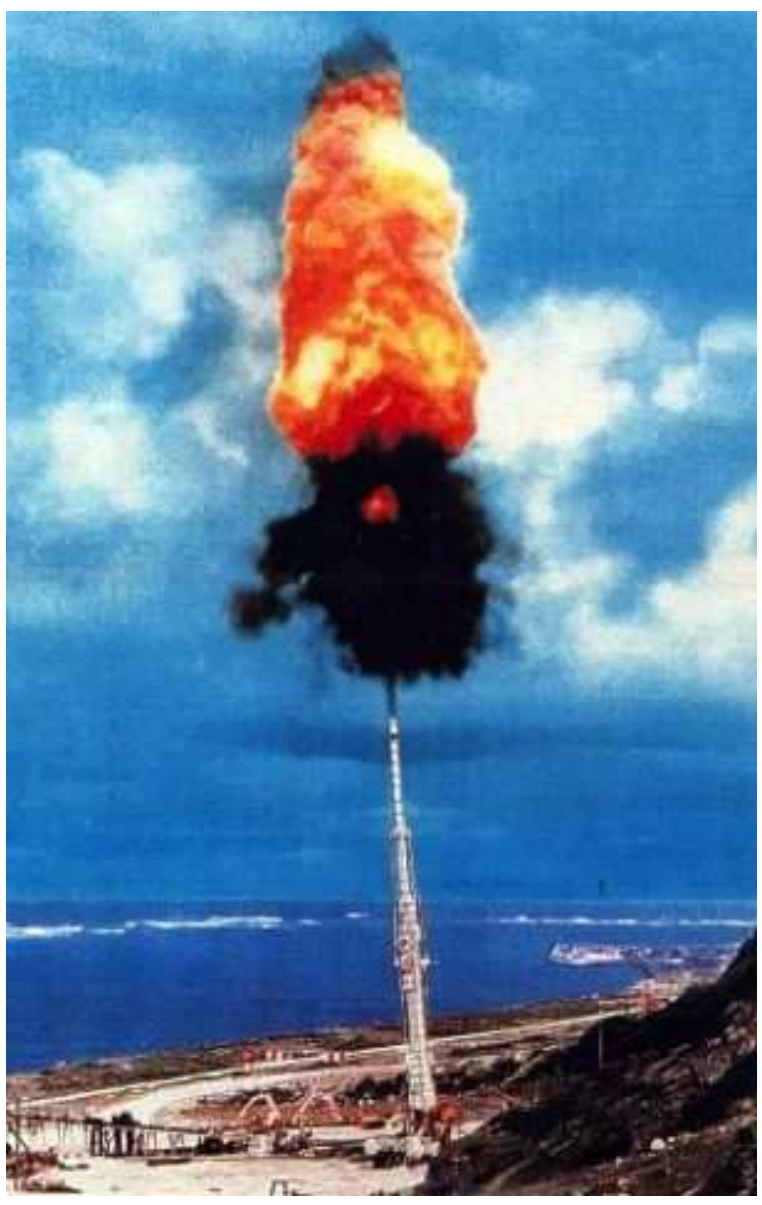

Fig. 1: HARP 16-inch (410 mm) gun in Barbados

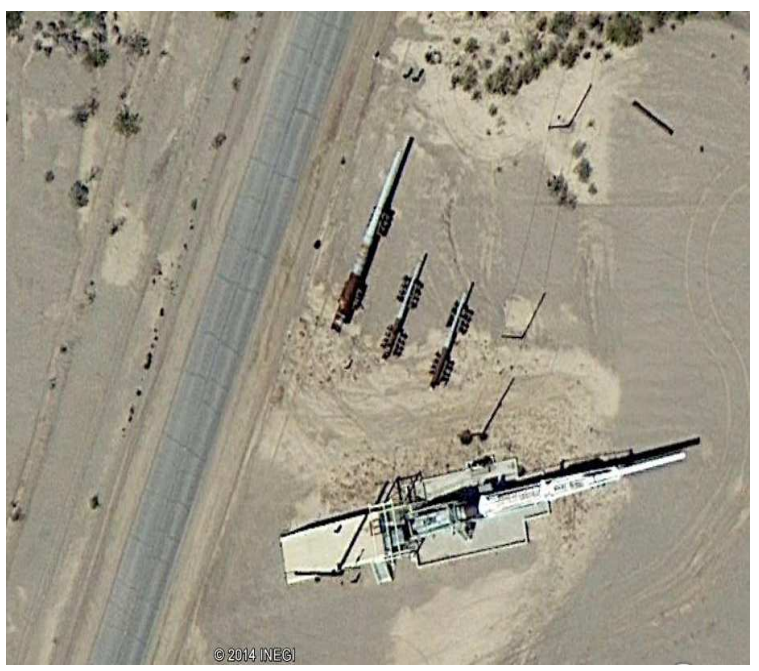

Fig. 2: HARP 16-inch $(410 \mathrm{~mm})$ gun in Yuma, Arizona

\section{Materials and Methods}

The HARP project was designed to develop missiles and projectiles launched with high-altitude weapons and 
to obtain scientific and technical data on the upper atmosphere and vehicle-environment interactions. In this effort, the 5 -inch pistols place $11.34 \mathrm{~kg}$ at 250,000 feet, 7-inch pistols place 27,216 kilograms at 33,000 feet and the 16-inch arms reach 59,000 feet, with 83,916 kilograms of projectiles. In addition, parachutes and aluminized chemicals have been launched to produce luminous paths for measuring wind from 100,000 feet to 59,000 feet, since at that time on-board telemetry units with temperature and electronic density sensors were in a high- an advanced development state. The 7-inch and 16-inch rocket weapons are under development and an attitude control system is under development for the 16-inch rocket.

By the end of 1966, the primary developmental teeth of the 5 and 7-inch systems took place on Wallops Island, Virginia and the only 16-inch vertical cannon was located on the Indian island of Western Barbados. Since all these tests involved the impact of water on the return of the projectiles, recovery of the useful tasks for development was very difficult when it was possible.

This was a severe limitation of the development of telemetry, antenna, different sensors and the altitude control unit at that time. At the beginning of 1965, it was decided to install a second 16-inch firewall from Yuma Proving Ground (YPG) in Arizona, with the ability to request permission to change the arms and eliminate the US's horizontal capacity.

Army Testing and Evaluation (TEC). The approval was received in March 1965, with an assigned project number. The vertical drawing was approved on November 24, 1965 and in August 1966 it was allowed to place a 5 -inch vertical tunnel near the 16 -inch cannon.

The excellent visibility from YPG, a very valuable issue for optical measurements of the upper atmosphere, has then become a side-but important benefit, which is why a scientific research program has been planned.

It is necessary to point out that the 16-inch HARP weapon was a joint effort between the McGill Institute for Space Research (SRI) and the American Blood Research Laboratories (BRL), with the SRI's principal and operational engineering.

All of these efforts were initiated with funding from the Armed Forces Research Office in 1962 and were fully funded until June 1964. At that time, a three-year joint US association was established and the Canadian Department of Defense Production. However, it should be noted that the establishment of a second 16-inch weapon in an armed test is no longer of interest to the Canadian government, although the specific tests of this armed unit have proved to be appropriate for the jointly funded program. For this reason, at the third meeting of the United States Joint Steering Committee for the HARP $=$ McGill project, which took place on 8 July
1965, the Space Research Institute was authorized to make the necessary changes for Yuma, the military.

In September 1965, the Yuma armament began with the arrival of an SRI resident engineer, Mr. Roy Kelly. The cylinder has been extended and the pillar has been modified for vertical fire.

A second Mark 7 barrel was obtained from the recreational harbor in Pocatello, Idaho and arranged there. A barrel of 150 barrel and a smooth sheet for a shoe extension were obtained. The 140-tonne barrel and the 30-tonne extension were then moved to Yuma on the landing route where the YPG cannula was located, where they were assembled into the canal support and welded together.

Another 15 tons of stiffening elements and connecting rods were welded to the expanded tube, so there was no bending during repeated pulls due to the canon's long canon. Finally, an 11-inch diameter cylinder with a length of 20 meters was built and the plant became operational for vertical fires on June 7, 1966. This report also describes the two radar arms and chairs YAMA, ionosonde and k-46, CV, taking into account the burning results of these weapons.

It should be noted that the 16 centimeters in Barbados and Yuma are not at all competitive. The scientific studies that can be performed on both plants provide data for two different latitudes (13, $10 \mathrm{~N}$ for Barbados and 32, $90 \mathrm{~N}$ for Yuma).

The Yuma $40 \times 10$ mileage range limits exposure to unauthorized flights to fully develop the projectiles but offers the possibility of recovery. Barbados's ability to shoot over water in the South Atlantic allows for longrange flights as well as missile and projectile flights.

Yuma Proving Ground is located in the Sonoran desert in the southwest corner of Arizona and is bordered to the west by the Colorado River. It is 40 miles from the Mexican border, 185 miles inside the country of San Diego, California, at the same distance west of Phoenix, Arizona. HARP guns are located at Gun 10 of the KOFA range, which extends east of Arizona State Highway 95 for approximately 40 miles.

The locations of the 16-inch gun and the special HARP instrumentation are given in Table 1 from the Fig. 3. In addition to these, both a fixed and mobile 250 $\mathrm{MHz}$ TM receiving station operated by YPG have supported HARP firings (Murphy and Bull, 1967; Petrescu and Petrescu, 2013a; 2013b; 2013c, 2012a; 2012b, 2011; Petrescu, 2009).

Always materials used to build aircraft have been a priority (Aversa et al., 2017a-; 2017b; 2017c; 2017d; 2017e; 2016a; 2016b; 2016c; 2016d; 2016e; 2016f; 2016g; 2016h; 2016i; 2016j; 2016k; 2016l; 2016m; 2016n; 2016o; Mirsayar et al., 2017). But at that time, there were no possibilities of today in creating of materials. 


\begin{tabular}{|c|c|c|c|}
\hline \multicolumn{4}{|c|}{ Table I. Location of HARP Equipment } \\
\hline & Latitude & Longitude & $\begin{array}{c}\text { Elevation } \\
\text { (meters) }\end{array}$ \\
\hline 16-inch gun & $32^{\circ} 52^{\prime} 33.2^{\prime \prime}$ & $114^{\circ} 19^{\prime} 31.7^{\prime \prime}$ & 141.9 \\
\hline MPS-19 radar & $32^{\circ} 52^{\prime} 26.7^{\prime \prime}$ & $114^{\circ} 20^{\prime} 8.3^{\prime \prime}$ & \\
\hline Ionosonde & $32^{\circ} 56^{\prime} 3.8^{\prime \prime}$ & $114^{\circ} 10^{\prime} 34.4^{\prime \prime}$ & \\
\hline K-46 Cameras & & & \\
\hline AWC, Yuma & $32^{\circ} 41^{\prime} 15.6^{\prime \prime}$ & $114^{\circ} 29^{\prime} 29.9^{\prime \prime}$ & 67.6 \\
\hline Blythe, Cal. & $33^{\circ} 36^{\prime} 27.1^{\prime \prime}$ & $114^{\circ} 35^{\prime} 29.7^{\prime \prime}$ & 81.7 \\
\hline Gila Bend, Ariz. & $32^{\circ} 56^{\prime} 42.6^{\prime \prime}$ & $114^{\circ} 43^{\prime} 50.5^{\prime \prime}$ & 221.0 \\
\hline
\end{tabular}

Fig. 3: The locations of the 16-inch gun and the special HARP instrumentation. Source: Murphy and Bull, 1967

\section{Results}

The 16-inch gun has a length of 119 feet and a fire on a nominal azimuth of 78.20. Its rammer charger system was designed by Rock Island Arsenal and is made up of two-wheeled vehicles.

The projectile is first placed in the charging tray of the first vehicle and the tray is then fed into the link. Once this vehicle is left behind, the second vehicle carrying a hydraulic cylinder is rolled forward, attached to the coupling and the projectile with its shoe is pushed forward with a maximum force of 50 tonnes in its position.

The gun tube was milled at a diameter of $16.40 \mathrm{~cm}$ and a length of $18.35 \mathrm{~cm}$ and a length of $70.1 \mathrm{~cm}$ and a longer length of $10.4 \mathrm{~cm}$ length of $83.8 \mathrm{~cm}$ and a section with a diameter of $16.9 \mathrm{~cm}$.

Six $1 / 4$ inch holes were punched at a distance of three, five feet of shoes on the southern side and two, four and six meters from the northern bot.

The electrical contacts placed in these holes are used to record the passing time of the projectile and therefore form a velocity measurement system.

The bottle is sealed before burning through a Mylar sheet and the hole is discharged into a tenth of atmosphere to achieve an estimated 150 feet per second increase.

The 5-inch extended drum is placed on a steel ramp 20 meters south of the 16-inch gun. It is 33 meters long, made of two $120-\mathrm{mm}$ T-123 barrels and placed in a $155 \mathrm{~mm}$ mobile holder.

This gun is loaded by a small hydraulic cylinder with a maximum force of 10 tons.

The 16-inch base projection is $185 \mathrm{~kg}$ Marlet $2 \mathrm{C}$ and is held in a gun with a 230-pound basic button.

The 5-inch HARP projectile weighs 20-23 pounds and is supported in its gun by a more sophisticated sabotage center weighing 5 pounds.

Both sabots separate from their projectiles shortly after launch and fall into a $1 / 2$ mile circle about their weapons. The performance of these missiles is shown in Fig. 4.

Three thousand two hundred meters behind the pistol's position are mounted MPS-19 mobile radar trucks in a Tband and connected through a small framing control desk.

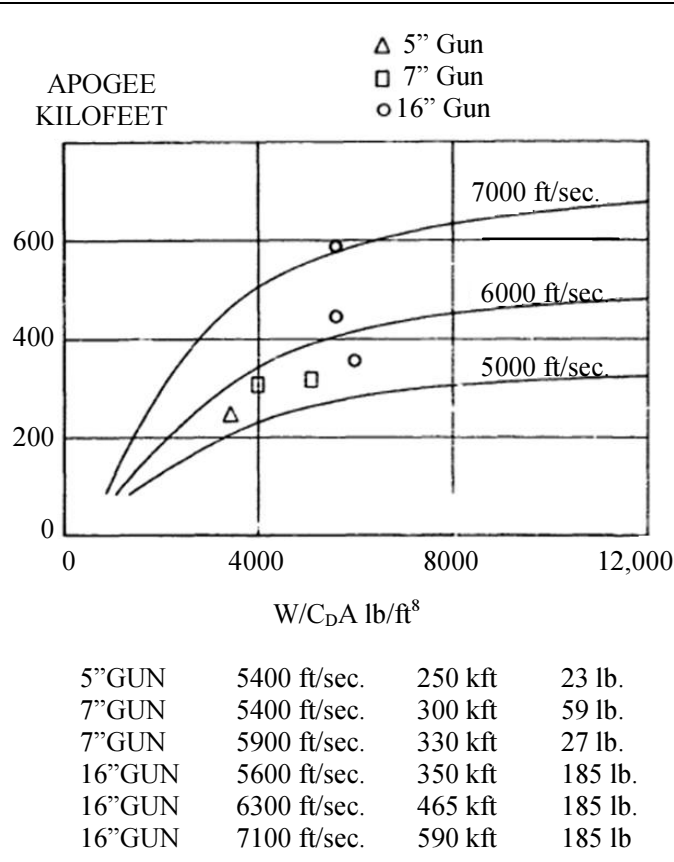

Fig. 4: Apogee for HARP glide vehicles. Source: Murphy and Bull, 1967

From this point of view, radio communication, telephone or intercom is available for the YPG control tower and other YPG reduction points, ionospheric points, k-46 locations, TM receiving stations and combustion circuit located in a trailer next to. This radar is identical to the one in the Barbados HARP series and Marlet 2C rocket projections up to 350,000 feet. Six times, this radar managed to regain Marlet $2 \mathrm{C}$ on the legs and provide the location and impact time. 5-inch projectiles can be purchased immediately after ejection and then tracked for the wind or soil recovery profiles.

The main scientific experiment conducted at YPG in 1966 involved the creation of light paths through trimetaluminium emission (TMA) and the measurement of photographic recordings of these trails to obtain wind profiles in the $90-180 \mathrm{~km}$ altitude range.

The core tools of the three K-24 locations at Yuma, Gila Bend and Blythe were designed, built and operated by BRL by Space Instruments Research, Inc. in Atlanta, Georgia.

Each station is made up of two K-46s mounted on a socket and a battery control unit. During each $30 \mathrm{sec}$ operating cycle, the cameras have 3, 6 and $9 \mathrm{sec}$ exposures and each movie frame is marked with exposure time, a number of photos and the location of the site in binary code. All sites are in a constant phone call with Launch control via a conference call.

In the northwest of the 25th century, near Tower 18.1, about 8.7 miles east and 6.2 miles north of the 16-inch gun, there is a towed ionosphere and a 60 -meter antenna tower.

This tool is administered by the ESSA Telecommunications and Aeronautical Sciences Institute 
in Boulder, Colorado during the firing series and provides measurements of the Sporadic E layer for the theoretical correlation with the measured ionospheric winds. In the south of the road, four antennas are located for remote measurements of the receptors of certain groups of electrons.

These measurements were taken for the first time in November 1966 and an analysis of the electron cloud velocity and a comparison with the neutral wind is ongoing.

In 1966, three 16-inch combustion series were executed.

In June, an initial series of three wood sculptures and six TMAs were launched that carried out Martlet 2C to check the state of the pistol and the operational capability of the supporting tools.
The sixth model TMA-Martlet 2C and 1 Lahive 150 with TM were mainly dedicated to the engineering tests of the new multiple ignition systems for dust cone and telemetry performance, while TMS-Martlet 2C on the 17th ionosphere November 1962 was intense.

The data on the performance and dispersion of weapons are shown in Table II of Fig. 5.

Prior to the Yuma explosions, a major improvement in pistol performance occurred when the 51-meter gun was extended to the Barbados weapon, thus increasing the speed of the Martlet 2C shoe from 5600 feet per second to 6300 feet per second from 350,000 to 465,000 of legs. Barbados performance for web WM/M .225 and web M8M 0.220 is summarized in Table 3 of Fig. 6. Ignition was performed through a single pin in the lock block.

Table II. Sixteen-Inch Firings at YPG-1966

\begin{tabular}{|c|c|c|c|c|c|c|c|c|}
\hline \multirow{2}{*}{$\frac{\text { Date }}{\text { Jun } 7}$} & \multirow{2}{*}{$\begin{array}{l}\text { Local } \\
\text { time } \\
\text { MST } \\
1818\end{array}$} & $\begin{array}{l}\mathrm{Rd}^{1} \\
\text { No. }\end{array}$ & rformance & $\begin{array}{l}\text { wt } \\
\mathrm{Lb}\end{array}$ & \multicolumn{2}{|c|}{$\begin{array}{l}\text { Pressure } \\
\text { kilo-1b/in } \\
\text { M11 Gage }\end{array}$} & \multirow{2}{*}{$\begin{array}{c}\begin{array}{c}\text { Muzzle } \\
\text { Vel }\end{array} \\
\frac{\text { Ft } / \mathrm{Sec}}{3360^{4}}\end{array}$} & \multirow{2}{*}{$\begin{array}{l}\text { Apogee } \\
\text { Kilofeet } \\
\text { No track }\end{array}$} \\
\hline & & 001(w) & NAVY & $\overline{700}$ & 13.0 & $\overline{----}$ & & \\
\hline 8 & 1927 & 002(w) & NAVY & 800 & 14.4 & $14.1 \mathrm{~S}$ & $3190^{4}$ & No track \\
\hline 13 & 1228 & $003(w)$ & WMM & 660 & 21.3 & $20.6 \mathrm{~S}$ & $4810^{4}$ & No track \\
\hline 13 & 2025 & 004 & WMM & 760 & 40.0 & ---- & 5930 & 415 \\
\hline 13 & 2215 & 005 & WMM & 780 & 33.2 & $31.9 \mathrm{~S}$ & 5810 & 398 \\
\hline 14 & 2146 & 006 & WMM & 780 & 44.0 & $42.7 \mathrm{~S}$ & 6060 & 400 \\
\hline 14 & 2317 & 007 & WMM & 800 & 51.4 & $50 . \theta \mathrm{S}$ & 6270 & Damaged \\
\hline 15 & 0127 & 008 & WMM & 760 & 29.8 & $30.0 \mathrm{~T}$ & 5630 & 375 \\
\hline 15 & 0305 & 009 & WMM & 780 & 34.6 & $33.0 \mathrm{~T}$ & 5850 & 410 \\
\hline Oct 25 & 2159 & 010 & $\operatorname{NAVY}\left(\mathrm{M}^{*}\right)$ & 1095 & 34.9 & ---- & 5250 & 310 \\
\hline 26 & 2055 & 011 & $\operatorname{NAVY}\left(\mathrm{M}^{*}\right)$ & 1225 & 50.3 & $43.5 \mathrm{~K}$ & 5950 & 410 \\
\hline 26 & 2356 & 012 & WMM (M) & 920 & 54.4 & $47.0 \mathrm{~K}$ & 6800 & 540 \\
\hline 27 & 1547 & $013(\mathrm{~L})$ & WMM (M) & 900 & 45.6 & --- & 7100 & No track \\
\hline 27 & 1952 & 014 & $\operatorname{NAVY}\left(M^{*}\right)$ & 1275 & 51.7 & $44.0 \mathrm{~K}$ & 5900 & 415 \\
\hline 27 & 2146 & 015 & WMM (M) & 920 & 53.5 & $46.0 \mathrm{~K}$ & 6780 & 535 \\
\hline 27 & 2320 & 016 & WMM (M) & 950 & 60.0 & $54.0 \mathrm{~K}$ & 7040 & Damaged \\
\hline Nov 16 & 1814 & 017 & $\operatorname{NAVY}\left(\mathrm{M}^{*}\right)$ & 1290 & 47.7 & --- & $5900^{4}$ & $396^{6}$ \\
\hline 16 & 2041 & 018 & NAVY $\left(M^{*}\right)$ & 1292 & 56.4 & $49.4 \mathrm{~K}$ & $5900^{4}$ & 395 \\
\hline
\end{tabular}

Table II. Sixteen-Inch Firings at YPG-1966 (Continued)

\begin{tabular}{|c|c|c|c|c|c|c|c|c|}
\hline \multirow{2}{*}{$\frac{\text { Date }}{\text { Nov } 16}$} & \multirow{2}{*}{$\begin{array}{l}\text { Local } \\
\text { time } \\
\text { MST } \\
2231\end{array}$} & \multirow{2}{*}{$\begin{array}{l}\mathrm{Rd}^{1} \\
\text { No. } \\
019\end{array}$} & \multirow{2}{*}{$\frac{\text { Powder }^{2}}{\operatorname{NAVY}\left(M^{*}\right)}$} & \multirow{2}{*}{$\begin{array}{l}\text { wt } \\
\frac{\mathrm{Lb}}{1296}\end{array}$} & \multicolumn{2}{|c|}{$\begin{array}{c}\begin{array}{c}\text { Pressure } \\
\text { kilo-1b/in }\end{array} \\
\text { M11 Gage } \\
\end{array}$} & \multirow{2}{*}{$\begin{array}{c}\text { Muzzle } \\
\text { Vel } \\
\mathrm{Ft} / \mathrm{Sec}\end{array}$} & \multirow{2}{*}{$\begin{array}{c}\begin{array}{c}\text { Apogee } \\
\text { Kilofeet }\end{array} \\
375\end{array}$} \\
\hline & & & & & 48.5 & $49.5 \mathrm{~K}$ & & \\
\hline 17 & 0015 & 020 & $\operatorname{NAVY}\left(\mathrm{M}^{*}\right)$ & 1296 & 47.5 & $45.0 \mathrm{~K}$ & & 415 \\
\hline 17 & 0316 & 021 & $\operatorname{NAVY}\left(\mathrm{M}^{*}\right)$ & 1290 & 60.8 & ---- & ---- & Damaged \\
\hline 18 & 1820 & 022 & $\operatorname{NAVY}\left(\mathrm{M}^{*}\right)$ & 1263 & 49.3 & ---- & $5900^{4}$ & 400 \\
\hline 18 & 2012 & 023 & $\operatorname{NAVY}\left(\mathrm{M}^{*}\right)$ & 1263 & 53.9 & $48.8 \mathrm{~K}$ & $\begin{array}{l}5850 \\
6650\end{array}$ & 410 \\
\hline 18 & 2149 & 024 & WMM (M) & 922 & 51.0 & $46.3 \mathrm{~K}$ & $\begin{array}{l}6650 \\
6650\end{array}$ & 510 \\
\hline 18 & 2342 & 025 & W8M (M) & 880 & 44.0 & $38.7 \mathrm{~K}$ & $6400^{5}$ & 490 \\
\hline 19 & 0100 & 026 & W8M (M) & 910 & 46.7 & $40.6 \mathrm{~K}$ & $6650^{5}$ & 530 \\
\hline 19 & 0234 & 027 & $\operatorname{NAVY}\left(\mathrm{M}^{*}\right)$ & 1270 & 45.9 & $42.5 \mathrm{~K}$ & $5850^{5}$ & 400 \\
\hline 19 & 0451 & 028 & W8M (M) & 960 & 57.5 & $51.3 \mathrm{~K}$ & $7000^{5}$ & 590 \\
\hline 19 & 0608 & 029 & $\operatorname{NAVY}\left(\mathrm{M}^{*}\right)$ & 1270 & 50.3 & $45.0 \mathrm{~K}$ & ---- & Damaged \\
\hline 19 & 1944 & 030 & W8M (M) & 960 & 42.7 & $38.8 \mathrm{~K}$ & $6350^{5}$ & 480 \\
\hline 19 & 2120 & 031 & $\operatorname{NAVY}\left(\mathrm{M}^{*}\right)$ & 1270 & 39.8 & $41.3 \mathrm{~K}$ & $5650^{5}$ & $367^{6}$ \\
\hline 19 & 2237 & 032 & $\operatorname{NAVY}\left(\mathrm{M}^{*}\right)$ & 1270 & 43.8 & $43.1 \mathrm{~K}$ & $5650^{5}$ & 370 \\
\hline 19 & 2358 & 033 & W8M $\left(\mathrm{M}^{*}\right)$ & 880 & 50.2 & ---- & $6750^{5}$ & 550 \\
\hline $\begin{array}{l}\text { (L) Lahiv } \\
{ }^{2} \text { M-multi } \\
{ }^{3} \text { S-strain } \\
{ }^{4} \text { No vacu } \\
{ }^{5} \text { Velocity } \\
{ }^{6} \text { Angoee }\end{array}$ & $\begin{array}{l}\text { T); T-To } \\
\text { her shot }\end{array}$ & $\begin{array}{l}\text { e gage } \\
\text { n barr }\end{array}$ & $\begin{array}{l}\text {; flight wt } 185 \mathrm{I} \\
\text { with shear lip on } \\
\text { ler gage. } \\
\text { ated to } 0.1 \mathrm{~atm} \text {. }\end{array}$ & $\begin{array}{l}\text { except f } \\
\text { eplate. }\end{array}$ & 1) woo & & & \\
\hline
\end{tabular}


Table II. Sixteen-Inch Firings at YPG-1966 (Continued)

b) Martlet 2C Dispersion*

\begin{tabular}{|c|c|c|}
\hline Rd No. & $\begin{array}{l}\text { Apgoee } \\
\text { Kilofeet }\end{array}$ & $\begin{array}{c}\text { Elevation } \\
\text { Degrees }\end{array}$ \\
\hline 004 & 415 & 83.9 \\
\hline 005 & 398 & --- \\
\hline 006 & 400 & 83.6 \\
\hline 007 & Damaged & ---- \\
\hline 008 & 375 & 84.0 \\
\hline 009 & 410 & 84.2 \\
\hline 010 & 310 & 85.0 \\
\hline 011 & 410 & 85.0 \\
\hline 012 & 540 & 85.0 \\
\hline 014 & 415 & 84.2 \\
\hline 015 & 535 & 84.5 \\
\hline 016 & Damaged & --- \\
\hline 017 & 369 & --- \\
\hline 018 & 395 & 84.5 \\
\hline 019 & 375 & 83.5 \\
\hline 020 & 415 & 83.9 \\
\hline 021 & Damaged & ---- \\
\hline 022 & 400 & 83.9 \\
\hline 023 & 410 & 83.6 \\
\hline 024 & 510 & 84.3 \\
\hline 025 & 490 & 83.6 \\
\hline 026 & 530 & 83.8 \\
\hline 027 & 400 & 83.7 \\
\hline 028 & 590 & 84.8 \\
\hline 029 & Damaged & ---- \\
\hline 030 & 480 & 83.5 \\
\hline 031 & 367 & ---- \\
\hline 032 & 370 & 83.4 \\
\hline 033 & 550 & 84.2 \\
\hline
\end{tabular}

\begin{tabular}{|c|c|}
\hline $\begin{array}{c}\text { Azimuth } \\
\text { degrees }\end{array}$ & $\begin{array}{c}\text { Impact range } \\
\text { Kilofeet }\end{array}$ \\
\hline $77(79.6)$ & $161 \mathrm{E}(158)$ \\
\hline ---- & --- \\
\hline $83(84.2)$ & 164E (159) \\
\hline---- & --- \\
\hline 72 & $144 \mathrm{E}$ \\
\hline $72(75.0)$ & $149 \mathrm{E}(146)$ \\
\hline 74 & $100 \mathrm{E}$ \\
\hline 78 & 129 \\
\hline 72 & $167 \mathrm{E}$ \\
\hline 80 & 153 \\
\hline 76 & 167 \\
\hline ---- & ---- \\
\hline---- & ---- \\
\hline 78 & $137 \mathrm{E}$ \\
\hline 79 & $153 \mathrm{E}$ \\
\hline 76 & $161 \mathrm{E}$ \\
\hline --- & --- \\
\hline 74 & $156 \mathrm{E}$ \\
\hline 76 & $167 \mathrm{E}$ \\
\hline 70 & $182 \mathrm{E}$ \\
\hline 81 & $196 \mathrm{E}$ \\
\hline 77 & $207 \mathrm{E}$ \\
\hline 76 & $162 \mathrm{E}$ \\
\hline 75 & $188 \mathrm{E}$ \\
\hline--- & ---- \\
\hline 78 & $198 \mathrm{E}$ \\
\hline 78 & 149 \\
\hline 79 & 155 \\
\hline 74 & $201 \mathrm{E}$ \\
\hline
\end{tabular}

Fig. 5: Gun performance and dispersion data are summarized. Source: Source: Murphy and Bull, 1967

Table III. Barbados Gun performance

a) Single point ignition, $220 \mathrm{M} 8 \mathrm{M}$

$$
\mathrm{p}>38,000 \text { psi }
$$

\begin{tabular}{|c|c|c|c|c|c|c|}
\hline \multirow[b]{2}{*}{ Date } & \multirow{2}{*}{$\begin{array}{l}\mathrm{Rd}^{3} \\
\text { No. }\end{array}$} & \multicolumn{4}{|c|}{ Pressure kilo-1b/in. ${ }^{2}$} & \multirow{2}{*}{$\begin{array}{l}\text { Apgoee } \\
\text { Kilofeet } \\
\end{array}$} \\
\hline & & wt. & Mil & Strain gage & MV & \\
\hline 24 Mar 65 & 098 & 750 & $45.8^{1}$ & 45.3 & $6100 \mathrm{R}$ & $\mathrm{k} 27$ \\
\hline 28 Mar 65 & 104 & 725 & $38.8^{1}$ & 38.9 & 5820 & 389 \\
\hline 28 Mar 65 & 105 & 730 & $38.6^{1}$ & 37.8 & 5750 & 384 \\
\hline 11 July 65 & 125 & 780 & 44.8 & 41.8 & $6160 \mathrm{R}$ & $436^{2}$ \\
\hline 12 July 65 & 126 & 790 & 49.3 & 45.2 & $6160 \mathrm{R}$ & 444 \\
\hline 12 July 65 & 127 & 780 & 44.1 & 40.8 & $6140 \mathrm{R}$ & 438 \\
\hline 17 Nov 65 & 7 & 750 & 40.8 & 41.0 & $6000^{4 !}$ & 390 \\
\hline 17 Nov 65 & 8 & 750 & 37.9 & 37.5 & $5940 \mathrm{R}$ & 404 \\
\hline 17 Nov 65 & 10 & 770 & 41.1 & 41.4 & $6120^{4}$ & 400 \\
\hline 18 Nov 65 & 11 & 770 & 35.0 & 40.2 & $5970^{4}$ & 408 \\
\hline 18 Nov 65 & 13 & 750 & 42.2 & 42.4 & $6050 \mathrm{R}^{4}$ & 421 \\
\hline 18 Nov 65 & 14 & 750 & 38.0 & 40.7 & $5800 \mathrm{R}$ & 380 \\
\hline 21 Nov 65 & 19 & 780 & 39.8 & 39.0 & $6130^{4}$ & 414 \\
\hline
\end{tabular}

${ }^{1}$ MK 6 gages.

${ }^{2}$ Gun elevation was $82.5^{\circ}$ for all other shots, it was $85^{\circ}$.

${ }^{3}$ If round number has not been assigned, number in series is given.

${ }^{4}$ Bore was evacuated to $0.1 \mathrm{~atm}$.

R-Velocity estimated from radar. 
Table III. Barbados Gun performance (Continued)

b) Single point, spaced charge, $225 \mathrm{WM} / \mathrm{M}$

\begin{tabular}{|c|c|c|c|c|c|c|}
\hline Date & $\begin{array}{l}\mathrm{Rd}^{*} \\
\text { No. }\end{array}$ & $\begin{array}{c}\text { Charge } \\
\text { wt. }\end{array}$ & Presst & Strain gage & MV & $\begin{array}{l}\text { Apgoee } \\
\text { Kilofeet }\end{array}$ \\
\hline $24 \mathrm{Feb} 66$ & 15 & 850 & 54.0 & 46.0 & $5900 \mathrm{R}^{\dagger}$ & 395 \\
\hline $24 \mathrm{Feb} 66$ & 16 & 850 & 51.0 & ---- & $6080 \mathrm{R}^{\dagger}$ & 426 \\
\hline $24 \mathrm{Feb} 66$ & 17 & 850 & 48.6 & ---- & $5760 \mathrm{R}$ & 377 \\
\hline 28 Sept 66 & 1 & 825 & 53.5 & 52.3 & $\dagger$ & 300 \\
\hline 28 Sept 66 & 2 & 825 & 53.6 & 52.4 & $\dagger$ & 414 \\
\hline 28 Sept 66 & 3 & 825 & 49.8 & 49.4 & $6200 \mathrm{R}^{\dagger}$ & 442 \\
\hline 29 Sept 66 & 4 & 780 & 45.2 & ---- & $\dagger$ & 386 \\
\hline 29 Sept 66 & 5 & 825 & 47.6 & 47.0 & $\dagger$ & 356 \\
\hline 29 Sept 66 & 6 & 825 & 48.1 & 48.5 & --- & 373 \\
\hline 29 Sept 66 & 7 & 825 & 55.1 & 54.3 & $\dagger$ & 392 \\
\hline & 8 & 825 & 55.7 & 53.4 & $\dagger$ & 415 \\
\hline 29 Sept 60 & 9 & 825 & 46.3 & 44.6 & $\dagger$ & 402 \\
\hline
\end{tabular}

${ }^{*}$ Round number is number in given series

'Bore was evacuated to $0.1 \mathrm{~atm}$.

R-Velocity was estimated from radar

"This round struck 4 inches short of seating position with 100 tons of

ram force applied. Charge was, therefore, reduced 45 pounds.

Fig. 6: The Barbados performance for WM/M 0.225 web and M8M 0.220 web is summarized in Table $3 a-b$. Source: Murphy and Bull (1967)

\section{Discussion}

In 1965, a step in increasing the pressure for compression pressure records was observed on a regular basis. Since the length of the load was used up to $130 \mathrm{~cm}$ to $190 \mathrm{~cm}$ in the room, it is believed that this step was caused by the shock waves formed between the tip of the dust bag and the thrust plate. Three wooden spacers were inserted to ensure that the final powder bag is in contact with the thrust plate and that the free volume was divided into three thirds, evenly spaced. This change eliminated the step in the pressure curve but reduced the peak pressure for the fixed load weight by 6-8000 psi. Thus, with a remote load, it is necessary to increase the weight of the load. Since November 1965, all 16-inch HARPs have used remote charges.

Table 3 (Fig. 6) and in particular Table 3b, shows considerable pressure and drainage pressure for the same load. Some of these variations are due to the pressure required by the ram, but it is believed that most damage caused by the small shield or a single projectile point can create perforated bags. In August 1966, it was decided to develop multiple ignition systems to simultaneously ignite dust bags.

The usual load of the powder consists of seventy kilograms of black diapers filled at the bottom. Pairs of centimeters were sewn into the dust bags of the other dust bags and connected in parallel with the combustion circuit. The bags were loaded so that each sponge bag had black patch patches in contact with a protective bag. Each bag was in direct contact with two aggressors.

This ignition system was first tested at the SRI's Highwater Laboratory, a 20-inch power gun. This change also had the effect of reducing the pressure for a fixed load, but, more importantly, it seemed to be a significant improvement in the speed of the shoe. The October Yuma series confirmed this improvement with a record high of 540000 feet and a record speed of 7,100 feet per second. In November, a record peak of 590000 feet $(180 \mathrm{~km})$ was established.

In spite of the scattering of data, it is possible, to sum up, the improvement of multiple ignition performances. For a pressure leak, the 44,000 psi M8M cylinder has a single point and the displaced cylinder will give 6250 feet per second and a peak of 460,000 feet, while the addition of multiple combustions raises that value to 6720 feet per second and 530,000 feet. Similarly, $\mathrm{WM} / \mathrm{M}$ at a drain pressure of 50000 psi produces 6,200 feet per second and 44,000 feet for the ignition with a point and an improvement of 6,800 feet per second and 54,000 feet for multiple ignitions.

At the beginning of the HARP program, it is hoped that large 16-inch stocks could be used, but this powder, designed to launch 2,700 pounds at 2,500 feet per 
second, burns too slowly for HARP's highperformance projectiles. The first gun marches in June used marine fuel and the leakage pressure of over 14000 psi could not be produced. As a final effort to use this cheap available fuel, it has decided to ignite more points on high-powered marine propulsion. To accelerate its combustion characteristics, the shear lips were placed on the pusher plates to keep them in position until reaching about 3000 psi. High-end tests were promising and Yuma's burning showed that this could be successfully used to reach 400,000 feet. Because the cost of dust is equal to the cost of metal parts for cars, for missions that require moderate altitude, the use of marine fuel costs half the cost of the shot. It is interesting to note that the maximum weight of 1296 pounds is almost twice as high as the 660 pounds load service and is the largest load ever used by a 16-inch gun.

Even though these cannons are now abandoned, they have fulfilled their mission, demonstrating and obtaining important data at that time. Some scientists still think to use such devices to determine atmospheric movement or to pick up objects without rockets in the atmosphere. Personally, we believe that balloons, guided ships and other modern ships can successfully accomplish these missions without great effort or damage. However, high altitude weapons and highspeed combustion systems can be used successfully in our planet's military defense techniques, in addition to missiles, LASERS and MASTERS of high power, explosives and explosives with different intensities shipped quickly and with very long distances.

Of course, this does not necessarily mean resuming tests on similar devices, but rather replacing them with stronger sounds.

\section{Conclusion}

Yuma Proving Ground 5 and 16-inch weapons and associated instruments and flight results for 1966 are described in detail.

The introduction of multi-point ignition for the 16inch pistol produced a new record of 111 miles using special propulsion and a moderate propulsion of $77 \mathrm{~km}$. Twenty-four ionospheric wind profiles were obtained from 16-inch firearms and 15 stratospheric firing profiles. Telemetric performance and soil recovery capacity have been demonstrated.

Even though these cannons are now abandoned, they have fulfilled their mission, demonstrating and obtaining important data at that time.

Some scientists still think to use such devices to determine atmospheric movement or to pick up objects without rockets in the atmosphere.

Personally, we believe that balloons, guided ships and other modern ships can successfully accomplish these missions without great effort or damage.
However, high altitude weapons and high-speed combustion systems can be used successfully in our planet's military defense techniques, besides high-power missiles, LASERS and MASTER, explosions and explosives with varying and very long changes.

\section{Acknowledgement}

We acknowledge and thank Mr Taher M. AbuLebdeh, Associate Prof at North Carolina A and T State Univesity, United States and Mr Muftah H. El-Naas PhD MCIC FICCE QAFCO Chair Professor in Chemical Process Engineering Gas Processing Center College of Engineering Qatar University and Ms Shweta Agarwala, Senior Research Scientist at Singapore Center for 3D Printing Nanyang Technological University Singapore for their suggestions and comments.

\section{Author's Contributions}

All the authors contributed equally to prepare, develop and carry out this manuscript.

\section{Ethics}

This article is original and contains unpublished material. The corresponding author confirms that all of the other authors have read and approved the manuscript and no ethical issues involved.

\section{References}

Aversa, R., F.I.T. Petrescu, R.V. Petrescu and A. Apicella, 2016a. Biomimetic FEA bone modeling for customized hybrid biological prostheses development. Am. J. Applied Sci., 13: 1060-1067. DOI: 10.3844/ajassp.2016.1060.1067

Aversa, R., D. Parcesepe, R.V. Petrescu, G. Chen and F.I.T. Petrescu et al., 2016b. Glassy amorphous metal injection molded induced morphological defects. Am. J. Applied Sci., 13: 1476-1482. DOI: 10.3844/ajassp.2016.1476.1482

Aversa, R., R.V. Petrescu, F.I.T. Petrescu and A. Apicella, 2016c. Smart-factory: Optimization and process control of composite centrifuged pipes. Am. J. Applied Sci., 13: 1330-1341.

DOI: 10.3844/ajassp.2016.1330.1341

Aversa, R., F. Tamburrino, R.V. Petrescu, F.I.T. Petrescu and M. Artur et al., $2016 \mathrm{~d}$. Biomechanically inspired shape memory effect machines driven by muscle like acting NiTi alloys. Am. J. Applied Sci., 13: 1264-1271. DOI: 10.3844/ajassp.2016.1264.1271

Aversa, R., E.M. Buzea, R.V. Petrescu, A. Apicella and M. Neacsa et al., 2016e. Present a mechatronic system having able to determine the concentration of carotenoids. Am. J. Eng. Applied Sci., 9: 1106-1111. DOI: 10.3844/ajeassp.2016.1106.1111 
Aversa, R., R.V. Petrescu, R. Sorrentino, F.I.T. Petrescu and A. Apicella, 2016f. Hybrid ceramo-polymeric nanocomposite for biomimetic scaffolds design and preparation. Am. J. Eng. Applied Sci., 9: 1096-1105. DOI: 10.3844/ajeassp.2016.1096.1105

Aversa, R., V. Perrotta, R.V. Petrescu, C. Misiano and F.I.T. Petrescu et al., 2016g. From structural colors to super-hydrophobicity and achromatic transparent protective coatings: Ion plating plasma assisted $\mathrm{TiO} 2$ and $\mathrm{SiO} 2$ Nano-film deposition. Am. J. Eng. Applied Sci., 9: 1037-1045. DOI: $10.3844 /$ ajeassp.2016.1037.1045

Aversa, R., R.V. Petrescu, F.I.T. Petrescu and A. Apicella, 2016h. Biomimetic and evolutionary design driven innovation in sustainable products development. Am. J. Eng. Applied Sci., 9: 1027-1036. DOI: 10.3844/ajeassp.2016.1027.1036

Aversa, R., R.V. Petrescu, A. Apicella and F.I.T. Petrescu, 2016i. Mitochondria are naturally micro robots-a review. Am. J. Eng. Applied Sci., 9: 991-1002. DOI: 10.3844/ajeassp.2016.991.1002

Aversa, R., R.V. Petrescu, A. Apicella and F.I.T. Petrescu, 2016j. We are addicted to vitamins $\mathrm{C}$ and E-A review. Am. J. Eng. Applied Sci., 9: 1003-1018.

DOI: 10.3844 ajeassp.2016.1003.1018

Aversa, R., R.V. Petrescu, A. Apicella and F.I.T. Petrescu, 2016k. Physiologic human fluids and swelling behavior of hydrophilic biocompatible hybrid ceramo-polymeric materials. Am. J. Eng. Applied Sci., 9: 962-972. DOI: 10.3844 /ajeassp.2016.962.972

Aversa, R., R.V. Petrescu, A. Apicella and F.I.T. Petrescu, 20161. One can slow down the aging through antioxidants. Am. J. Eng. Applied Sci., 9: 1112-1126. DOI: 10.3844/ajeassp.2016.1112.1126

Aversa, R., R.V. Petrescu, A. Apicella and F.I.T. Petrescu, 2016m. About homeopathy or «Similia similibus curentur $\gg$. Am. J. Eng. Applied Sci., 9: 1164-1172. DOI: 10.3844/ajeassp.2016.1164.1172

Aversa, R., R.V. Petrescu, A. Apicella and F.I.T. Petrescu, 2016n. The basic elements of life's. Am. J. Eng. Applied Sci., 9: 1189-1197. DOI: 10.3844/ajeassp.2016.1189.1197

Aversa, R., F.I.T. Petrescu, R.V. Petrescu and A. Apicella, 2016o. Flexible stem trabecular prostheses. Am. J. Eng. Applied Sci., 9: 1213-1221. DOI: 10.3844/ajeassp.2016.1213.1221

Aversa, R., R.V.V. Petrescu, A. Apicella and F.I.T. Petrescu, 2017a. Nano-diamond hybrid materials for structural biomedical application. Am. J. Biochem. Biotechnol., 13: 34-41.

DOI: 10.3844/ajbbsp.2017.34.41
Aversa, R., R.V. Petrescu, B. Akash, R.B. Bucinell and J.M. Corchado et al., 2017b. Kinematics and forces to a new model forging manipulator. Am. J. Applied Sci., 14: 60-80. DOI: 10.3844/ajassp.2017.60.80

Aversa, R., R.V. Petrescu, A. Apicella, I.T.F. Petrescu and J.K. Calautit et al., 2017c. Something about the $\mathrm{V}$ engines design. Am. J. Applied Sci., 14: 34-52. DOI: 10.3844/ajassp.2017.34.52

Aversa, R., D. Parcesepe, R.V.V. Petrescu, F. Berto and G. Chen et al., 2017d. Process ability of bulk metallic glasses. Am. J. Applied Sci., 14: 294-301. DOI: 10.3844/ajassp.2017.294.301

Aversa, R., R.V.V. Petrescu, B. Akash, R.B. Bucinell and J.M. Corchado et al., 2017e. Something about the balancing of thermal motors. Am. J. Eng. Applied Sci., 10: 200.217. DOI: 10.3844/ajeassp.2017.200.217

Mirsayar, M.M., V.A. Joneidi, R.V.V. Petrescu, F.I.T. Petrescu and F. Berto, 2017. Extended MTSN criterion for fracture analysis of soda lime glass. Eng. Fracture Mechanics, 178: 50-59.

DOI: $10.1016 /$ j.engfracmech.2017.04.018

Murphy, C.H. and G.V. Bull, 1967. HARP 5-inch and 16-inch guns at Yuma proving ground, Arizona, Memorandum report no. 1825.

Petrescu, F.I. and R.V. Petrescu, 2011. Memories About Flight. 1st Edn., CreateSpace, pp: 652.

Petrescu, R.V. and FIT. Petrescu, 2012a. Northrop. Books on Demand, ISBN-13: 978-3848209323, pp: 142.

Petrescu, F.I. and R.V. Petrescu, 2012b. New Aircraft II. 1 st Edn., Books on Demand, pp: 138.

Petrescu, F.I.T., 2009. New aircraft. Proceedings of the 3rd International Conference on Computational Mechanics, Oct. 29-30, Brasov, Romania.

Petrescu, R.V. and F.I. Petrescu, 2013a. Lockheed Martin. 1st Edn., CreateSpace, pp: 114.

Petrescu, R.V. and F.I. Petrescu, 2013b. Northrop. 1st Edn., CreateSpace, pp: 96.

Petrescu, R.V. and F.I. Petrescu, 2013c. The Aviation History or New Aircraft I Color. 1st Edn., CreateSpace, pp: 292.

HARP Project, Wikipedia, the free encyclopedia. https://en.wikipedia.org/wiki/Project_HARP

\section{Sources of Figure:}

Fig. 1:

https://history.stackexchange.com/questions/17701/wher e-is-or-was-project-harps-yuma-arizona-space-gun

Fig. 2:

https://history.stackexchange.com/questions/17701/wher e-is-or-was-project-harps-yuma-arizona-space-gun 